\title{
NUTRITIONAL EVALUATION OF DRIED TOMATO (LYCOPRISON ESCULINTUM) HAULMS INSTEAD OF ALFALFA HAY IN FEEDING GROWING RABBITS UNDER NORTH SINAI CONDITIONS.
}

\author{
E.O.A. Bakr ${ }^{1}$, H.M.F. Galal ${ }^{2}$ and H.EL-S. Abbas ${ }^{2}$ \\ ${ }^{1}$ Department of Animal and Poultry Production, Faculty of Environmental Agricultural Sciences, \\ Arish University, North Sinai, Egypt \\ ${ }^{2}$ Animal Production research institute, Agriculture research center. Dokki, Giza, Egypt
}

SUMMARY

$\mathrm{T}$ he study was conducted to evaluate the utilization of dried tomato (Lycoprison esculintum) haulms as instead of alfalfa hay in feeding growing rabbits. Thirty weaned New Zealand white rabbits of both sexes aged $7 \mathrm{wk}$ and weighted 970.80 were randomly divided into three groups (10 each). The first group (C) was fed the basal diet as control $(0 \% \mathrm{DTH})$, while the other two treatment groups (L and H). Were fed diets containing 10 and 20\% DTH, respectively replacing alfalfa hay in the basal diet. All the experimental diets contained nearly the same level of crude protein (CP) and digestible energy (DE). All the experimental diets formulated to cover the nutrients requirements of rabbits. The diets and fresh water were supplied ad-libitum during the experimental period ( $8 \mathrm{wk})$. At the end of experimental period, digestibility trials were carried out to determine the digestibility of feed nutrients and the feeding values of experimental diets. Three rabbits from each group were slaughtered to evaluate carcass traits and some blood parameters. Results indicated that the experimental diets with different levels of DTH $(\mathrm{L}$ and $\mathrm{H})$ showed no significant differences $(\mathrm{P}>0.05)$ among the dietary treatments in respect of live body weight, total weight gain and daily weight gain at different ages. Total feed intake and daily feed intake of DTH-diets were significant decreased compared to that of control diet during the first four weeks, while, were slightly decreased during the whale experimental period. Feed conversion did not affected significantly. All nutrients digestibility coefficients (DM, OM, CP, CF, EE and NFE) and Nutritive values as TDN did not effect by dietary treatment did not affected, while DCP was lower with H-diet than that of other diets (control diet and L-diet). Empty carcass as weight or percentage and total edible parts as weight were decreased significantly with H-diet comported with that of control diet, while the other traits of carcass were not affected by dietary treatments. There were no significant differences among dietary treatments in most blood constituents (Albumin, Glucose, Cholesterol, Urea-N, Creatinine, ALT and AST). Total protein (TP) and Globulin of rabbits fed on $\mathrm{H}$-diet were lower $(\mathrm{P}<0.05)$ than those fed C-diet. Economic efficiency (E.E) and Relative of DTH-diets were higher than C-diet.

Keywords: Rabbits, dried Tomato (Lycoprison esculintum) haulms, productive performance, digestibility, carcass traits, blood parameters and economic efficiency.

\section{INTRODUCTION}

In Egypt, there is a wide nutritional gab between the available and that demand for meet to nutritional requirements of livestock. This gab is continuously increasing because of limited land and irrigation water and increasing human population. So, several searches have made to decrease this gab by using crop residues and agro-industrial by-products in animal feeding. There are annually about 38.28 million tons of field crop residues and using of them is estimated about $39 \%$ as animal feeds (Agricultural statistics, Economic affaire sectors, Ministry of Agriculture, 2011).

Vegetable crop residues are the plant parts that remained after harvesting of vegetable crops. Most of them used as organic fertilizers or burned causing environmental pollution and subsequent health hazard, but a little are dried and stored as forage sources for ruminants or left in the field as grazing for animals (Renard, 2001). Crop tomato (lycopriscon esculintum) is considered main vegetable crop in Egypt. Crop area of them is estimated about 537582 fedan produce about 1881537 tons of tomato haulms (Agricultural statistics, Economic affaire sectors, Ministry of Agriculture, 2011). Tomato (lycopriscon esculintum) haulms can be used in ruminant feeding as forage where it having $14.88 \% \mathrm{CP}, 1.85 \% \mathrm{EE}, 43.59 \% \mathrm{CF}$ and $30.71 \%$ NFE (EL-sayed et al., 2012).

Issued by the Egyptian Society of Nutrition and Feeds 
Therefore, the present study aimed to study the effective inclusion of dried tomato (lycopriscon esculintum) haulms instead of alfalfa hay as untraditional feed ingredient in rabbit diets on growth performance, digestibility of nutrients, carcass traits and some blood constituents.

\section{MATERIALS AND METHODS}

This experiment was conducted in the rabbitry farm of the Department of Animal and Poultry Production, Faculty of Environmental Agriculture Sciences, Arish University, North Sinai, Egypt for 8 weeks starting 19-5 to 13-7-2021.

\section{Preparation of dried tomato (lycopriscon esculintum) haulms (DTH)}

Tomato (lycopriscon esculintum) haulms $(\mathrm{TH})$ were collected from EL-Saleheya city, Sharqia governorate, Egypt. TH were air dried under shade until their moisture content reached almost $10 \%$, then completely ground and stored in a well tight polyethylene bags at room temperature until they were used. Samples of dry Tomato haulms (DTH) were taken for chemical analysis. DTH was analyzed for crude protein (CP), crude fiber (CF), ether extract (EE) and ash according to A. O. A. C (2012).

\section{Experimental design and management}

Thirty newly weaned New Zealand White (NZW) rabbits of both sexes at 7 weeks ages were assigned to three similar groups, each of 10 animals according to their initial live body weight $(970.80 \pm 24.51 \mathrm{~g})$. Rabbits of each group were sub-divided into three replicates of 3, 3 and 4 animals. The experimental period lasted 56 days (from 7 to $15 \mathrm{wks}$ of age). The $1^{\text {st }}$ treatment group (control, C\%) was fed a pelleted control diet; the $2^{\text {nd }}$ and $3^{\text {rd }}$ treatment groups ( $\mathrm{L}$ and $\mathrm{H}$ ) were fed diets containing 10 and $20 \% \mathrm{DTH}$ substituting $33.3 \%$ and $66.6 \%$ alfalfa hay respectively (Table 1). DTH was handily mixed with feed ingredients and the experimental diets were pelleted under a temperature of $70{ }^{\circ} \mathrm{C}$ and $0.3 \mathrm{~cm}$ diameter and $2 \mathrm{~cm}$ length. The experimental diets were formulated to be iso-nitrogenous $(\approx 17 \% \mathrm{CP})$, iso-caloric $(2500 \mathrm{kcal} \mathrm{DE} / \mathrm{Kg}$ diet $)$ and cover the recommended nutrients requirements of growing rabbits according to NRC (1996). Ingredient and calculated chemical composition of the experimental diets are showed in Table (1). Rabbits were housed in galvanized wire cages (3/cage) measured $(40 * 40 * 30 \mathrm{~cm})$ in a wellventilated building (natural air and light throw the window). Cages were provided with feeders and automatic nipple drinkers. The experimental diets and fresh water were offered ad-libitum twice daily at 8.00 AM and 6.00 PM. All rabbits were observed daily, kept under the same managerial, hygienic and environmental conditions. All rabbits were individually weighed at the beginning of the experiment, then weekly before offering the morning meal until end of experiment. Feed intake was recorded weekly during the experimental period. Live body weight, weight gain, feed intake, feed conversion ratio ( $\mathrm{g}$ feed/ $\mathrm{g}$ gain) and economic efficiency were estimated.

\section{Digestibility trials}

At the end of the growth experimental period ( $15 \mathrm{wk}$ of age), digestibility trials were conducted to evaluate the nutrient's digestibility and feeding values of the experimental diets. Three male rabbits were chosen randomly from each group and housed individually in metabolism cages facilitate the collection of feces. The same feeding regime used during the feeding trial was also used during the digestibility trial. A preliminary period of 10 days was followed by 5 days as a collection period for feces. The experimental diets were offered once a day at 8.00 AM ad-libitum. Feed intake was recorded daily and quantitative collection of feces was started 24 hours after offering the daily feed. The feces of each rabbit were collected daily in the morning for a collection period of 5 days. Any shaded hair or foreign materials were discarded. The feces were sprayed with $2 \%$ boric acid for trapping any ammonia released, then was dried at $60{ }^{\circ} \mathrm{C}$ for 36 hours. At the end of the collection period, all dried feces for each rabbit was mixed, grounded and stored until chemical analysis. Diets and feces were analyzed according to A. O. A. C (2012). The nutritive values of the experimental diets were estimated as digestible crude protein (DCP $\%$ ), and total digestible nutrients (TDN) Values of total digestible nutrients (TDN) were calculated according to the equation described by Cheeke et al. (1982) as follows:

$$
\mathrm{TDN} \%=\% \mathrm{DCP}+\% \mathrm{DCF}+\% \mathrm{DNFE}+2.25(\% \mathrm{DEE}) .
$$

\section{Carcass traits}

At the end of experimental period (15 wk of age), three rabbits representing each dietary treatment were randomly chosen to estimate carcass traits. Rabbits were fasted for approximately 12 hours and 
individually weighted to record the pre-slaughter weight. After complete bleeding and skinning, the empty carcass with head, liver, kidneys and heart were weighted separately according to Cheeke (1987).

Table (1): Ingredients and calculated chemical composition of the experimental diets (as fed).

\begin{tabular}{|c|c|c|c|}
\hline \multirow{2}{*}{ Item } & \multicolumn{3}{|c|}{ The experimental diets ${ }^{1}$} \\
\hline & $\mathrm{C}$ & $\mathrm{L}$ & $\mathrm{H}$ \\
\hline Alfalfa hay (15\%) & 30.00 & 20.00 & 10.00 \\
\hline Dried tomato haulm (DTH) & - & 10.00 & 20.00 \\
\hline Yellow corn & 21.00 & 21.14 & 23.69 \\
\hline Soybean meal (44\%) & 18.00 & 17.60 & 18.00 \\
\hline Wheat bran & 24.19 & 24.40 & 21.00 \\
\hline Molasses & 4.00 & 4.00 & 4.00 \\
\hline Di-Methionine & 0.11 & 0.11 & 0.11 \\
\hline Vitamins and mineral mixture $^{2}$ & 0.30 & 0.30 & 0.30 \\
\hline Salt & 0.50 & 0.50 & 0.50 \\
\hline Limestone & 1.35 & 1.40 & 1.65 \\
\hline Di-Calcium phosphate & 0.35 & 0.35 & 0.55 \\
\hline Anti-fungi & 0.10 & 0.10 & 0.10 \\
\hline Anti-coccidian & 0.10 & 0.10 & 0.10 \\
\hline Total & 100 & 100 & 100 \\
\hline \multicolumn{4}{|l|}{ Calculated analysis ${ }^{3}$. } \\
\hline Dry matter (DM)\% & 87.04 & 87.01 & 87.00 \\
\hline Organic matter $(\mathrm{OM}) \%$ & 81.09 & 81.15 & 81.36 \\
\hline Crude protein $(\mathrm{CP}) \%$ & 17.00 & 17.00 & 17.00 \\
\hline Ether extract (EE)\% & 2.67 & 2.63 & 2.56 \\
\hline Nitrogen free extract (NFE)\% & 47.96 & 47.15 & 46.82 \\
\hline Ash $\%$ & 5.95 & 5.86 & 5.64 \\
\hline Digestable energy $(\mathrm{DE})^{4}, \mathrm{kcal} / \mathrm{Kg}$ & 2500 & 2500 & 2500 \\
\hline Crude fiber $(\mathrm{CF}) \%$ & 13.46 & 14.36 & 14.98 \\
\hline $\mathrm{NDF} \%$ & 37.77 & 38.36 & 38.77 \\
\hline $\mathrm{ADF} \%$ & 21.71 & 22.53 & 23.10 \\
\hline Hemicellulose \% & 16.06 & 15.83 & 15.67 \\
\hline Calcium $\%$ & 1.13 & 1.01 & 1.00 \\
\hline Total phosphorus $\%$ & 0.535 & 0.510 & 0.500 \\
\hline Methionine\% & 0.38 & 0.36 & 0.34 \\
\hline Lysine & 0.82 & 0.75 & 0.71 \\
\hline $\mathrm{DE}: \mathrm{CP}$ & 147.06 & 147.06 & 147.06 \\
\hline \multicolumn{4}{|c|}{$\begin{array}{l}{ }^{1} \text { Experimental diets; } C=\text { control diet, containing no DTH; } L=\text { diet containing } 10 \% D T H ; H=\text { diet containing } 20 \% \\
\text { DTH. }\end{array}$} \\
\hline \multicolumn{4}{|c|}{$\begin{array}{l}{ }^{2} \text { Each } 3 \mathrm{~kg} \text { of premix contains: Vit. A } 6000000 \mathrm{iu} \text {, Vit. D3 } 900000 \mathrm{iu} \text {, Vit. E } 40000 \mathrm{mg} \text {, VIt k3 } 2000 \mathrm{mg} \text {, Vit. B1 } 2000 \\
\text { mg, Vit. B2 } 4000 \mathrm{mg} \text {, Vit. B6 } 2000 \mathrm{mg} \text {,Vit.B12 } 10 \mathrm{mg}, \text { Biotin } 50 \mathrm{mg} \text {, Pantothenic acid } 10000 \mathrm{mg} \text {, Nicotinic acid } 50000 \\
\text { mg, Folic acid } 3000 \mathrm{mg} \text {, Choline chloride } 250000 \mathrm{mg}, \text { Mg } 8500 \mathrm{mg} \text {, Zinc } 50000 \mathrm{mg} \text {, Iron } 50000 \mathrm{mg} \text {, Copper } 5000 \\
\text { mg, Iodine } 200 \mathrm{mg} \text {, Selenium } 100 \mathrm{mg} \text { and Cobalt } 100 \mathrm{mg} \text {. } \\
3 \text { according to (MOA 2001). }\end{array}$} \\
\hline
\end{tabular}

\section{RESULTS AND DISCUSSION}

\section{Temperature- humidity index (THI)}

In this study, overall averages of temperature and relative humidity were $29.76^{\circ} \mathrm{C}$ and $63.24 \%$, respectively. The calculated mean THI was 28.01 indicated that the rabbits were reared under moderate heat stress (Marai et al., 2001). 


\section{Productive performance:}

As shown in table (2), No significant differences were observed among the three dietary treatments in respect of live body weight, total weight gain and daily weight gain at different ages (from 7 to 15 weeks). Slightly decreasing was observed due to inclusion of DTH in the mentioned traits. Decreasing daily weight gain of all rabbits in the present study than that obtained by (Bakr et al 2019 and Bakr, 2019) for the same of rabbit strain may be due to heat stress. Viability percentage of rabbits were 90,100 and $90 \%$ for the three dietary treatments (control diet, $\mathrm{C}$; $\mathrm{L}$ and $\mathrm{H}$ ), respectively.

Table (2): Live body weight and daily gain of growing rabbits as influenced by dietary treatments.

\begin{tabular}{|c|c|c|c|c|}
\hline \multirow{2}{*}{ Item } & \multicolumn{3}{|c|}{ Treatments $^{1}$} & \multirow{2}{*}{ P-Value ${ }^{2}$} \\
\hline & Control, $\mathrm{C}$ & $\mathrm{L}$ & $\mathrm{H}$ & \\
\hline \multicolumn{5}{|l|}{ Live body weight $(\mathrm{g})$ : } \\
\hline Initial (7 wk). & $968.80 \pm 26.65$ & $970.80 \pm 24.51$ & $970.10 \pm 24.96$ & 0.998 \\
\hline 11 wks. & $1578.22 \pm 53.16$ & $1561.80 \pm 28.56$ & $1518.22 \pm 29.61$ & 0.536 \\
\hline 15 wks. & $1969.56 \pm 55.16$ & $1970.40 \pm 38.41$ & $1897.22 \pm 49.00$ & 0.475 \\
\hline \multicolumn{5}{|l|}{ Total weight gain $(\mathrm{g})$ : } \\
\hline 7-11 wks. & $613.44 \pm 37.46$ & $591.00 \pm 24.87$ & $534.44 \pm 33.14$ & 0.224 \\
\hline $11-15$ wks. & $391.33 \pm 28.70$ & $408.60 \pm 23.04$ & $379.00 \pm 32.17$ & 0.751 \\
\hline 7-15 wks. & $1004.78 \pm 50.15$ & $999.60 \pm 32.79$ & $913.44 \pm 54.14$ & 0.310 \\
\hline \multicolumn{5}{|l|}{ Daily weight gain $(\mathrm{g})$ : } \\
\hline 7-11 wks. & $21.91 \pm 1.34$ & $21.11 \pm 0.89$ & $19.09 \pm 1.18$ & 0.224 \\
\hline $11-15$ wks. & $13.98 \pm 1.02$ & $14.59 \pm 0.82$ & $13.53 \pm 1.15$ & 0.751 \\
\hline $7-15 \mathrm{wks}$ & $17.94 \pm 0.89$ & $17.85 \pm 0.59$ & $16.31 \pm 0.97$ & 0.308 \\
\hline No. of animals: & 10 & 10 & 10 & - \\
\hline No. of dead animals. & 1 & - & 1 & - \\
\hline Viability \%. & 90 & 100 & 90 & - \\
\hline
\end{tabular}

Table (3). Feed intake and feed conversion ratio as influenced by dietary treatments.

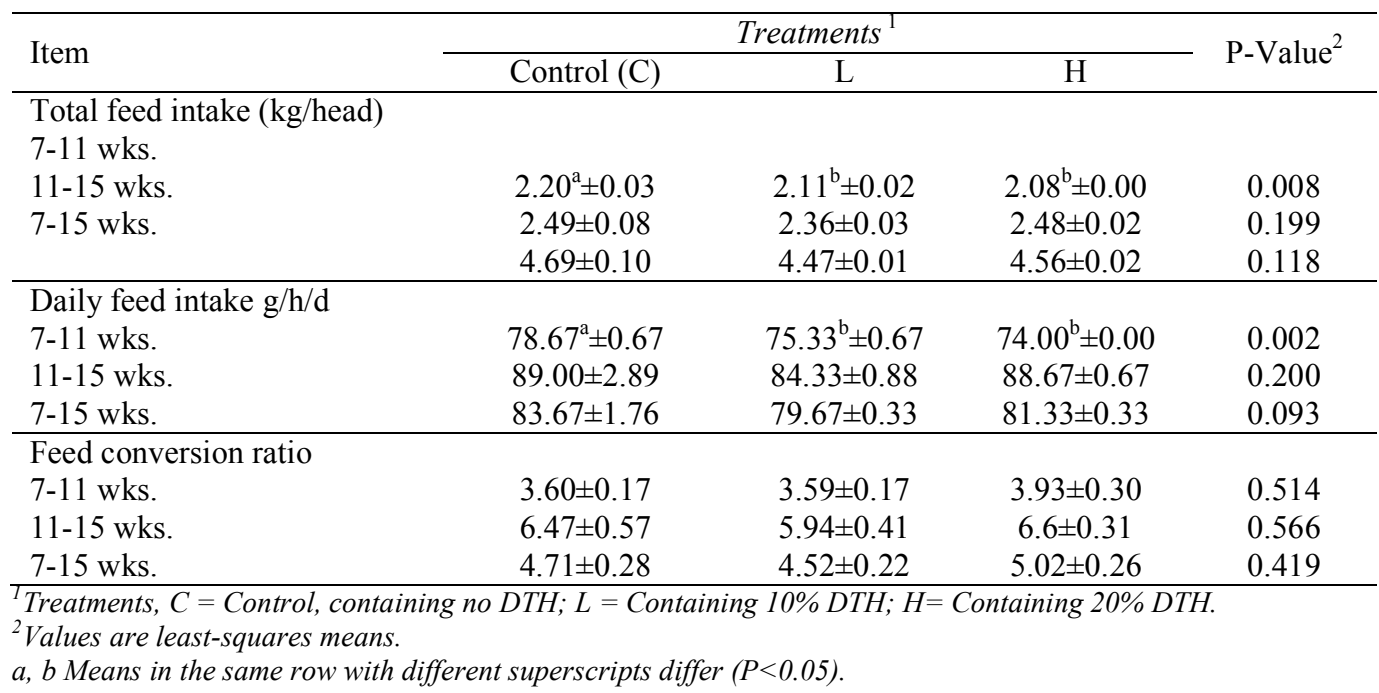

Total feed intake and daily feed intake of diets contained DTH (Land $\mathrm{H})$ were significant $(\mathrm{P}<0.01)$ decreased compared to that of control diet during the period $(7-11 \mathrm{wks})$ while they were nearly comparable during the periods $(11-15$ wks and $7-15$ wks) for the dietary treatments (Table 3 ). Decreasing total feed intake and daily feed intake of DTH diets during (7-11 wk of age) may be due to the oxalate effect which is considerably working as major factor contributing to the anti-palatability (Ravindran et al., 1996, Agwunobi et al., 2002 and Amany et al, 2017). Regarding feed conversion ratio, results cleared that no significant effect due to inclusion of DTH into the rabbit diets during the different ages (from $7-15 \mathrm{wk}$ ). The $2^{\text {nd }}$ group (L) had the 
best values $(3.59,5.94$ and 4.52$)$ and the $3^{\text {rd }}$ group $(H)$ had the lowest values $(3.93,6.6$ and 5.02). From pervious results, it mean that DTH could be incorporated in the rabbit diets up to $\mathrm{H}$ level (20\%) without causing adverse effect on the productive performance.

\section{Nutrients digestibility and nutritive values of experimental diets}

Table (4) showed that all nutrients digestibility coefficients were not significant $(\mathrm{P}>0.05)$ among treatments. Digestion coefficients of $\mathrm{CP}$ and $\mathrm{CF}$ tended to be lower in rabbits fed on diets containing DTH. In the same way, total digestible nutrients (TDN) did not differ significantly among treatments. Meanwhile, digestible crude protein (DCP) of rabbits fed H-diet $(20 \%)$ was lower $(\mathrm{P}<0.05)$ than that fed DTH-free diet (control diet).

Decreasing digestibility coefficients (CP and $\mathrm{CF}$ ) and digestible crude protein (DCP)of rabbits fed DTH diet might be due to the oxalate effect which is considered working as major factor contributing to the anti-palatability effect (Agwunobi et al 2002 an Salem, 2020)

Table (4): Effect of dietary containing of different levels of dary tomato haulms (DTH) on apparent nutrients digestion coefficients and nutritive values of the experimental diets.

\begin{tabular}{|c|c|c|c|c|}
\hline \multirow{2}{*}{ Parameter } & \multicolumn{3}{|c|}{ Treatment $^{1}$} & \multirow{2}{*}{ P-Value } \\
\hline & Control (C) & $\mathrm{L}$ & $\mathrm{H}$ & \\
\hline \multicolumn{5}{|c|}{$\begin{array}{l}\text { Digestibility coefficient } \\
(\%)\end{array}$} \\
\hline (DM) & $65.49 \pm 2.34$ & $65.58 \pm 1.51$ & $64.07 \pm 1.60$ & 0.82 \\
\hline (OM) & $67.52 \pm 2.05$ & $67.53 \pm 1.54$ & $65.86 \pm 1.57$ & 0.75 \\
\hline $\mathrm{CP}$ & $78.04 \pm 2.89$ & $76.11 \pm 3.25$ & $68.19 \pm 3.05$ & 0.13 \\
\hline $\mathrm{EE}$ & $80.03 \pm 1.44$ & $77.26 \pm 3.14$ & $76.32 \pm 2.24$ & 0.55 \\
\hline $\mathrm{CF}$ & $28.15 \pm 4.98$ & $24.83 \pm 2.89$ & $19.25 \pm 0.60$ & 0.24 \\
\hline NFE & $74.45 \pm 1.90$ & $74.83 \pm 1.85$ & $75.97 \pm 1.01$ & 0.80 \\
\hline \multicolumn{5}{|c|}{$\begin{array}{l}\text { Nutritive values } \\
(\%)\end{array}$} \\
\hline TDN & $65.22 \pm 2.38$ & $63.96 \pm 1.48$ & $62.17 \pm 1.14$ & 0.50 \\
\hline DCP & $15.13^{\mathrm{a}} \pm 0.56$ & $14.20^{\mathrm{ab}} \pm 0.61$ & $12.31^{b} \pm 0.55$ & 0.03 \\
\hline
\end{tabular}

${ }^{1}$ Treatments, $C=$ Control, containing no DTH; $L=$ Containing $10 \%$ DTH;

$H=$ Containing $20 \%$ DTH. ${ }^{2}$ Values are least-squares means.

$a, b$ Means in the same row with different superscripts differ $(P<0.05)$.

\section{Carcass traits}

All carcass traits either weight or percentage of pre-slaughter were unaffected significantly $(\mathrm{p}>0.05)$ by dietary treatments. In respect of dressing percentage, the highest value being occurred with control group $(\mathrm{C}, 66.84 \%)$ versus (63.39 and $63.64 \%$ ) for groups $\mathrm{L}$ and $\mathrm{H}$, respectively (table 5). These results indicated that using DTH up to $20 \%$ had not adverse effects on carcass traits and the internal organs (liver, kidneys and heart) were appeared normal in size and did not show any signs of toxicity.

\section{Blood constituents}

Data presented in Table (6) showed that inclusion of dried tomato haulms (DTH) in rabbit diets up to $20 \%$ had no significant effect on most of selected serum constituents (except total protein, Globulin and $\mathrm{Alb} /$ Glo ratio) which were significantly lower in the group $(\mathrm{H})$ than control group $(\mathrm{C})$. The significant decrease in serum total protein in group $(\mathrm{H})$ than that of control group $(\mathrm{C})$ could be attributed to lower degradability of protein in tomato haulm. However, it contains anti-nutritional factors such as tomatine, solanine, chaconine, lactins and oxalats (Khogali et al, 2010 cited by Novak and Haslberger, 2000). All serum constituents were within the normal range of healthy rabbits (Manning et al., 1994). The nonsignificant effects of the dietary treatments on most serum constituents may be due to the adequacy of nutrients. (Eggum, 1989; Onifade and Abu, 1998, Amany et al 2017 and Bakr et al, 2019). 
Table (5): Effect of the different levels of tomato haulm in growing New Zealand White rabbit diets on carcass characteristics

\begin{tabular}{|c|c|c|c|c|}
\hline \multirow[b]{2}{*}{ Item } & \multicolumn{3}{|l|}{ Treatments $^{1}$} & \multirow{2}{*}{-P-Value ${ }^{2}$} \\
\hline & Control (C) & $\mathrm{L}$ & $\mathrm{H}$ & \\
\hline Live-body weight (LBW) & $1949.33 \pm 16.80$ & $1933.00 \pm 33.86$ & $1884.00 \pm 49.79$ & 0.460 \\
\hline Empty carcass weight (g) & $1247.33 \pm 26.52$ & $1169.00 \pm 29.51$ & $1140.67 \pm 28.42$ & 0.084 \\
\hline$\%$ of LBW & $63.98 \pm 0.82$ & $60.48 \pm 1.25$ & $60.57 \pm 1.05$ & 0.094 \\
\hline Total edible parts $(\mathrm{g})^{3}$ & $1303.33 \pm 28.26$ & $1225.00 \pm 27.84$ & $1198.67 \pm 30.77$ & 0.097 \\
\hline$\%$ of LBW(dressing) & $66.84 \pm 0.88$ & $63.39 \pm 1.33$ & $63.64 \pm 1.01$ & 0.118 \\
\hline Edible giblets $(\mathrm{g})^{4}$ & $56.00 \pm 2.52$ & $62.00 \pm 2.00$ & $58.00 \pm 3.06$ & 0.312 \\
\hline$\%$ of LBW & $2.87 \pm 0.11$ & $3.20 \pm 0.05$ & $3.08 \pm 0.08$ & 0.086 \\
\hline Head (g) & $118.33 \pm 2.33$ & $117.33 \pm 3.38$ & $111.67 \pm 1.76$ & 0.224 \\
\hline$\%$ of LBW & $6.07 \pm 0.13$ & $6.07 \pm 0.07$ & $5.93 \pm 0.19$ & 0.723 \\
\hline Liver(g) & $40.67 \pm 2.33$ & $47.00 \pm 2.08$ & $43.33 \pm 1.76$ & 0.176 \\
\hline$\%$ of LBW & $2.09^{\mathrm{a}} \pm 0.11$ & $2.43^{\mathrm{b}} \pm 0.07$ & $2.30^{\mathrm{ab}} \pm 0.03$ & 0.053 \\
\hline kidney (g) & $9.67 \pm 0.33$ & $9.67 \pm 0.33$ & $9.67 \pm 0.33$ & 1.000 \\
\hline$\%$ of LBW & $0.50 \pm 0.01$ & $0.50 \pm 0.02$ & $0.51 \pm 0.01$ & 0.763 \\
\hline Heart (g) & $5.67 \pm 0.33$ & $5.33 \pm 0.88$ & $5.00 \pm 1.00$ & 0.842 \\
\hline$\%$ of LBW & $0.29 \pm 0.02$ & $0.28 \pm 0.05$ & $0.26 \pm 0.05$ & 0.895 \\
\hline
\end{tabular}

$\overline{a, b}$ Means in the same row with different superscripts differ $(P<0.05)$.

${ }^{1}$ Treatments; $C=$ Control, containing no DTH; $L=$ containing $10 \%$ DHT; $H=$ containing $20 \%$ DTH. ${ }^{2}$ Values are leastsquares means.

${ }^{3}$ Total edible parts $w t .=$ empty carcass $w t .($ with head $)+$ edible giblets $w t$.

Total edible parts $\%=$ total edible parts $w$ t. /fasted $w t . * 100$

${ }^{4}$ Edible giblets $w t .=$ Liver + Kidneys $w t .+$ Heart $w t$.

Table (6). Effect of the different levels of dried tomato haulm in growing New Zealand White rabbits' diets on some blood constituents.

\begin{tabular}{lcccc}
\hline Item & \multicolumn{3}{c}{ Treatments $^{1}$} & \multirow{2}{*}{ P-Value $^{2}$} \\
\cline { 2 - 4 } & Control (C) & L & H & 0.058 \\
Total protein g/dl & $6.50^{\mathrm{a}} \pm 0.14$ & $6.15^{\mathrm{ab}} \pm 0.09$ & $5.92^{\mathrm{b}} \pm 0.17$ & 0.978 \\
Albumin (g/dl) & $4.67 \pm 0.13$ & $4.67 \pm 0.09$ & $4.70 \pm 0.15$ & 0.018 \\
Globulin (g/dl) & $1.83^{\mathrm{a}} \pm 0.04$ & $1.49^{\mathrm{ab}} \pm 0.17$ & $1.22^{\mathrm{b}} \pm 0.05$ & 0.042 \\
Alb/Glo & $2.55^{\mathrm{b}} \pm 0.10$ & $3.24^{\mathrm{ab}} \pm 0.43$ & $3.88^{\mathrm{a}} \pm 0.19$ & 0.367 \\
Glucose (mg/dl) & $91.67 \pm 8.25$ & $93.67 \pm 1.45$ & $81.33 \pm 6.33$ & 0.142 \\
Cholesterol (mg/dl) & $45.33 \pm 0.67$ & $55.67 \pm 0.88$ & $51.00 \pm 5.29$ & 0.804 \\
Urea (mg/dl) & $42.33 \pm 0.88$ & $43.67 \pm 5.21$ & $45.33 \pm 1.45$ & 0.604 \\
Creatinine (mg/dl) & $1.66 \pm 0.16$ & $1.51 \pm 0.08$ & $1.60 \pm 0.02$ & 0.600 \\
AST (U/L) & $68.33 \pm 6.23$ & $59.00 \pm 6.81$ & $64.00 \pm 5.69$ & 0.883 \\
ALT (U/L) & $55.33 \pm 4.67$ & $50.00 \pm 7.00$ & $50.33 \pm 11.86$ & \\
\hline
\end{tabular}

${ }^{T}$ Treatments; $C=$ Control, containing no DTH; $L=$ containing $10 \% \mathrm{DTH} ; \mathrm{H}=$ containing $20 \% \mathrm{DTH}$. ${ }^{2}$ Values are leastsquares means.

${ }^{a, b}$ Means in the same row with different superscripts differ $(p<0.05)$.

\section{Economic efficiency}

It is evident that the lower price of tomato haulms was reflected on the price of the experimental diets. Feed cost / kg gain of the diets contains DTH ( $\mathrm{L}$ and $\mathrm{H}$ ) was decreased by 13.33 and $13.29 \%$ compared with that of control diet (C), respectively. Net revenue / rabbit (L.E), Economic efficiency (E. E) \% and Relative E.E (\%) of L-DTH diet (10\%) were higher than C-diet and H-DTH diet $(20 \%)$. These results were in agreement with those obtained by Amany et al (2017) and Salem (2020).

\section{CONCLUSION}

It could be concluded that the use of vegetable crop residues is necessary to reduce the price of feed, because feed cost is one of the main obstacles to the development of rabbit production. Therefore, dried tomato haulm $(\mathrm{DTH})$ could be used in feeding growing rabbits up to $20 \%$ of the diet replacing from 
Alfalfa hay with no harmful effects compared with feeding the commercial diet. In addition, due to the lower prices of dried tomato haulm compared to traditional feeds, the economic efficiency could be increased when using it as a substitute.

Table (7): Economic efficiency as affected by dried tomato haulms (DTH) in rabbits' diet.

\begin{tabular}{lccc}
\hline \multirow{2}{*}{ Item } & \multicolumn{3}{c}{ Treatments $^{*}$} \\
\cline { 2 - 4 } & Control (C) & $\mathrm{L}$ & $\mathrm{H}$ \\
\hline Price/kg diet. (L.E) & 5.07 & 4.76 & 4.51 \\
Total feed intake/rabbit(g) & 4.69 & 4.47 & 4.56 \\
Total feed cost/rabbit (L.E) & 23.78 & 21.28 & 20.56 \\
Total weight gain/rabbit(g) & 1004.78 & 999.60 & 913.44 \\
Feed cost/kg gain (L.E) & 23.68 & 21.27 & 22.52 \\
Price/kg weight gain (L.E) & 37 & 37 & 37 \\
Total revenue/weight gain(L.E) & 37.18 & 37 & 33.78 \\
Net revenue/rabbit (L.E) & 13.50 & 15.73 & 11.26 \\
Economic efficiency (E.E)\% & 57.01 & 73.95 & 0.50 \\
Relative E. E (\%) & 100 & 129.71 & 87.72 \\
\hline "Treammon
\end{tabular}

${ }^{*}$ Treatments, $C=$ Control, containing no DTH;

$L=$ Containing $10 \%$ DTH; $H=$ Containing $20 \%$ DTH.

Based on price of ingredients of the diets and market price of live body weight as $\mathrm{kg}$ during the experimental period (2021). The price of one ton of alfalfa hay, yellow corn, soybean meal (44\%), wheat bran and tomato haulm were $3400,5200,7800,3750$ and $500 \mathrm{LE}$, respectively and the price of $\mathrm{kg}$ of salt, lime stone, Di-calcium phosphate, premix, molasses, DL-methionine, Anti-fungi and Anti-coccidian were 1, 0.5, 12, 50, 3, 80, 42 and 150 LE. Price of live body weight as $\mathrm{kg}$ was $37 \mathrm{LE}$.

\section{REFERENCES}

A.O.A.C. (2012) Association of Official Analatical Chemists. Official methods of analysis. $19^{\text {th }} \mathrm{Ed}$. A.O.A.C. Washington. DC, USA.

Agricultural statistics, Economic affaire sectors, Ministry of Agricultures (2011).

Agwunobi, L.N., P.O. Angwukan, O.O. Cora and M.A. Isika (2002). Studies of the use of Colocasia esculenta (Taro cocoyam) in the diets of weaned pigs. Tropical Animal Health and Production. 34 (3): 241-247.

Amany A. Khayyl; E.O.A. Bakr; Y.L. Phillip; A.M. Hussein and A.A. Khir (2017). Effect of diets containing dried taro (colocasia esculanta) waste and dried yeast (saccharomycess cerevisiae) on performance of growing rabbits. J. Anim. And poultry prod. Mansoura Univ. Val. (6): 109-117.

Cheeke, P.R. (1987). Rabbit feeding and nutrition. Academic press. Ozlanda, Florida, U. S. A.

Cheeke, P.R.; N.M. Patton and G.S. Templeton (1982). Rabbit Production. $5^{\text {th }}$ Ed. Print and Published. USA.

Duncan, D.B. (1955). Multiple range and multiple F tests. Biometrics 11:1-42.

Eggum, B.O. (1989). Biochemical and methodological principles. In: Bock, H.D., B.O. Eggum, A.G. Low, O. Simon, T. Zebrowska (Eds), Protein Metabolism in Farm Animals. Evaluation, Digestion, Absorption, and metabolism. Oxford Science Publications, Deutscher Landwirtscafts Verlag, Berlin, pp.1-52.

El- Kerdawy, D.M.A. (1997). Olive pulp as a new energy source for growing rabbits. Egyptian journal of Rabbits Science, 7 (1): $1-12$.

EL-sayed, H.M; Z.H. Abd EL-Hamid; EL-SH.M. Ramadan; M.H.M. Yacout and H.EL-S. Abbas (2012). Study on the use of tomato vines in ruminant feeding. 1- Mitigation of impact of pesticide residues in tomato vines. Journal of environmental science, institute of environmental studies and research, Ain Shams University, Value (25), No, (1). 
Khogali. H; K. Faze; A. Gofoon and B. Ali (2010). Comparative study between tomato (lycopriscon esculintum) straw and ground nut hay for feeding male Sudanese desert sheep. J. of Agricultural Sciences of Damascus University, 2 (26): 301-309.

Manning, P.J., D.H. Ringler and C.E. New comer (1994). The Biology of Laboratory Rabbit, $2^{\text {nd }}$ ed. Academic press inc., San Diego, California, USA.

Marai, I.F.M., M.S. Ayyat and U.M. Abd EL-Monem (2001). Growth performance and reproductive traits at first parity of New Zealand white female rabbits as affected by heat stress and its alleviation under Egyptian conditions. Trop. Anim. Health prod., 32 (6): 451-462.

MOA (2001). Feed composition tables for Animal and Poultry feed stuff used in Egypt. Technical Bulletin No.1, central Lab for feed and food, Ministry of Agriculture, Egypt.

Novak, W.K and A.G. Haslberger (2000). Substantial equivalence of antinutrients and inherent plant toxins in genetically modified novel foods. Journal of Food and Chemical Toxicology. 38: 473-483.

NRC (1996). National research council nutrient requirements of rabbits. Washington, DC. USA.

Onifade, A.A. and O.A. Abu, (1998). Productive response of rabbits to supplemental copper in a diet based on tropical feedstuffs. J. Appl. Anim. Res., 13: 129-135.

Ravindran, V., R. Sivakanesan and H.W. Cyril (1996). Nutritive value of raw and processed colocasia (Colocasia esculenta) corm meal for poultry. Animal Feed Sci. \& Technology, 57 (4): 335-345.

Renard, C. (2001). Crop residues in mixed crop / livestock farming systems. CAB International in association with the association with the International Crops Research Institute for the Semi-Arid Tropics and the International Livestock Research Institute. Pp. 25-36.

Salem, W. A, (2020). Effect of using untraditional feeds on reproduction, growth and carcass characteristics of New-Zealand white rabbits in North Sinai. M. Sc., Thesis, Fac. Of Environmental Agricultural Sciences Arish University, Egypt.

Schiemann, R.; K. Nehring; L. Hoffman; W. Jentsch and A. Chudy (1972). Energetische futterbewertung und energienormen. VEB Deutscher Landwirtschaftsveriag. Berlin. 344.

SPSS (2007). User's guide: statistics. Version 16. SPSS Inc. Chicago, IL, USA. 
التقييم الغذائي لعرش الطماطم الجاف كبديل لاريس البرسيم الحجازي فى تغذية الأرانب النامية تحت ظروف شمال سيناء.

\author{
السيد عثمان عبدالنبي بكر 1, حسن محمد فؤاد جلال', حسن السيد عباس².

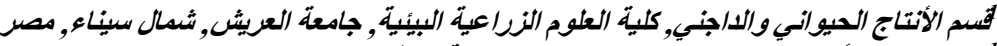

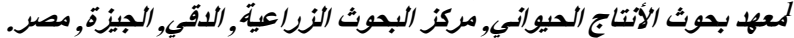

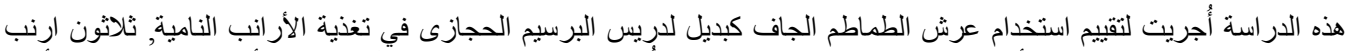

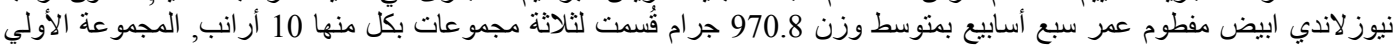

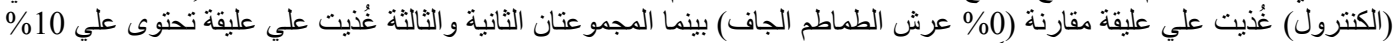

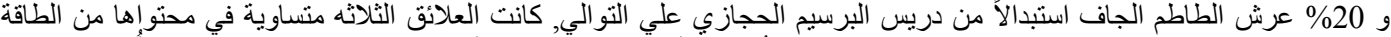

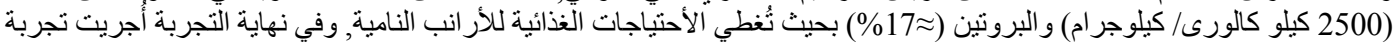

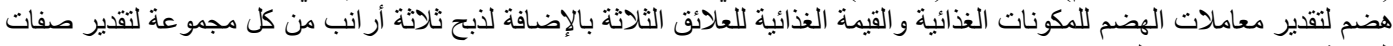
الذبيحة وبعض مكونات الدم .

أوضحت النتائج المتحصل عليها ما يلي:

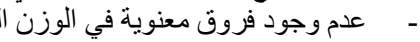

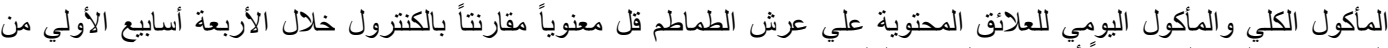

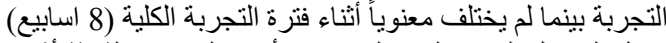

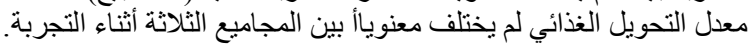
لم توجد اختلافات معنوية في معاملات الهضئ للمنائل للمركبات الغذائية و القيمة الغذائية في صورة مجموع المركبات الكلية المهضومة TDN بين المجاميع الثلاثة.

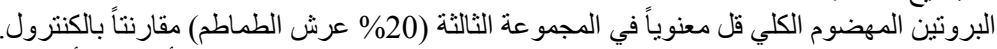

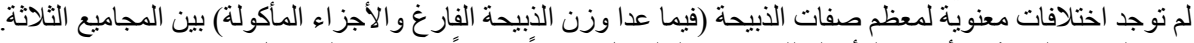

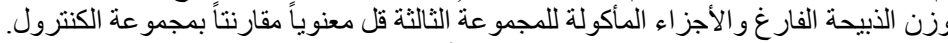
لم توجد اختلافات معنوية لمعظم مكونات الدم (الألبيومين, الجلوكوز, الكوليسترول, اليوريا, و الكرياتين, وأنزيمات الكبد الكبد البروتين الكلي والجلو بيولين قل معنوياً للمجموعة الثالثة مقارنتاً بمجموعة الكنترول بينما الألبيومين / الجلوبيولين للمجموعة الثالثة زاد

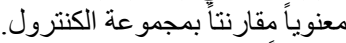
و عموماً كل مكونات الدام كانت في المستوي الطبيعي للأر انب النامية للمجاميع الثلاثنة.

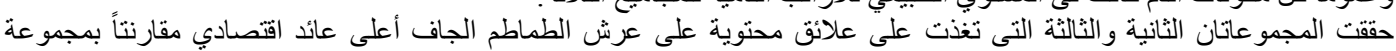
الكنترول.

الخلاصة : يمكن تغذية الأر انب النامية على علائق محتوية على عرش الطماطم الجاف حتي 20\% من العليقة اسنبدالاً من دريس البرسيم الحجازى دون أن يؤثر ذلك على الصفات الأنتاجية والفئ الفسيولوجية علئ للأر انب النامية. 